\title{
Peran Sektor Pertanian terhadap Perekonomian Kabupaten Hulu Sungai Utara
}

\section{(The Role of the Agriculture Sector in the Economy Hulu Sungai Utara Regency)}

\author{
Azwar Saihani' ${ }^{1)}$, Purna Kusumayana, ${ }^{2)}$ \& Laila Mayang Sari ${ }^{3)}$ \\ Program Studi Agribisnis, Sekolah Tinggi Ilmu Pertanian Amuntai \\ ${ }^{1)}$ Azwar.saihani63@yahoo.com \\ ${ }^{2)}$ kusumayanapurna@yahoo.com \\ ${ }^{3)}$ Mayang.brb.01@gmail.com
}

\begin{abstract}
ABSTRAK
Pembangunan sektor pertanian menjadi hal penting dalam perekonomian diantaranya potensi sumber daya alam yang besar dan beragam dengan karakteristik kondisi geografis yang berbeda sehingga memungkinkan keanekaragaman komoditas yang dihasilkan. Penelitian ini bertujuan mengetahui kontribusi, posisi, pertumbuhan, serta basis dan non basisnya tiap subsektor pertanian terhadap PDRB dalam perekonomian Kabupaten Hulu Sungai Utara dari tahun 2013-2017. Data yang digunakan adalah data sekunder yang berasal dari BPS dan instansi pemerintahan yang terkait. Metode analisis yang dipakai yaitu analisis kontribusi, tipologi klassen, shift share dan LQ. Penelitian dilakukan pada Bulan Januari-April 2019. Hasil penelitian menunjukkan bahwa semua subsektor pertanian dalam lima tahun terakhir mengalami nilai kontribusi yang turun naik atau tidak stabil, berada pada kuadran III yaitu sektor potensial atau masih bisa dikembangkan, subsektor perikanan, subsektor peternakan dan subsektor tanaman pangan mengalami pertumbuhan yang cepat atau mendapat nilai positif dalam pertumbuhan proposionalnya (Pp), mengalami pertumbuhan wilayah $(P w)$ yang kurang baik atau tidak kompetitif jika dibandingkan dengan wilayah-wilayah lain di Provinsi Kalimantan Selatan. Subsektor tanaman pangan, peternakan dan perikanan merupakan subsektor basis sedangkan subsektor hortikultura dan subsektor perkebunan adalah sub sektor non basis dalam perekonomian Kabupaten Hulu Sungai Utara. Subsektor tanaman pangan yang paling tinggi kontribusinya terhadap sektor pertanian di Kabupaten Hulu Sungai Utara.
\end{abstract}

Kata kunci: Perekonomian, pertanian, pertumbuhan, subsektor.

\section{ABSTRACT}

The development of the agricultural sector becomes important in the economy including the potential for large and diverse natural resources with different geographical conditions to enable the diversity of commodities produced. This study aims to determine the contribution, position, growth, and the basis and non-basis of each agricultural sub-sector to GRDP in the economy of Hulu Sungai Utara Regency from 2013-2017. The data used are secondary data from BPS and related government agencies. The analytical methods used are contribution analysis, classic typology, shift-share and LQ. The results showed that all agricultural sub-sectors in the last five years experienced up and down or unstable contribution values, located in quadrant III, which is the potential sector or can still be developed, the fisheries subsector, the livestock subsector and the food crops subsector have experienced rapid growth or received positive values in proportional growth (Pp), experiencing regional growth $(P w)$ which is not good or not competitive when compared to other regions in Kalimantan Selatan Province. The food crops, livestock and fisheries sub-sector is the basic subsector while the horticulture and plantation subsectors are the nonbase subsectors in the economy of the Hulu Sungai Utara Regency. The food crop subsector has the highest contribution to the agriculture sector in Hulu Sungai Utara Regency.

Keywords: Agriculture, economy, growth, subsector.

Article History Submitted: April 6, $2020 \quad$ Approved with minor revision: May 14, 2020

Accepted: May 21, 2020

Published: May 28, 2020 


\section{PENDAHULUAN}

Indonesia adalah negara agraris yang berarti negara yang mengandalkan sektor pertanian baik sebagai sumber mata pencaharian maupun sebagai penopang pembangunan. Pertumbuhan sektor pertanian yang tinggi serta membawa masyarakat tani menjadi lebih baik disebut pembangunan pertanian yang berhasil. Akan tetapi kekayaan hayati yang dimilliki Indonesia seperti keadaan geografisnya cenderung menyulitkan pemerataan pembangunan perekonomian di beberapa daerah di Indonesia. Sehingga pemerintah membuat kebijakan tentang otonomi daerah untuk memberikan kewenangan bagi pemerintah daerah dalam mengatur dan melaksanakan program-program daerahnya (Kuncoro, 2001). Salah satunya yaitu Kalimantan Selatan yang merupakan daerah yang menggunakan kebijakan otonomi dengan tujuan agar pembangunan bisa berjalan merata sehingga tingkat perekonomian masyarakatnya membaik.

Menurut data BPS tahun 2013-

2017 Kabuapaten Hulu Sungai Utara adalah penyumbang keenam terbesar pembentuk PDRB Kalimantan Selatan. Kabupaten Hulu Sungai Utara ekonominya bertumpu pada sektor pertanian. Hal ini dapat dilihat dari data PDRB Kabupaten Hulu Sungai Utara yang penyumbang terbesarnya adalah sektor pertanian. Penyumbang terbesar kemisikinan di Kabupaten Hulu Sungai Utara adalah sector pertanian. Berdasarkan data survei sosial ekonomi nasional (Susenas) 2016, sebesar 31,78 persen penduduk miskin di Kabupaten Hulu Sungai Utara bekerja di sektor pertanian. Kabupaten Hulu Sungai Utara meskipun masih menyandang status kabupaten tertinggal tetapi rata-rata pertumbuhan ekonominya dalam lima tahun terakhir paling tinggi di Kalimantan Selatan. Ini dikarenakan pada tahun 20152016 terjadi penurunan jumlah penduduk miskin sebesar 0,31 persen dan menjadi kabupaten dengan penurunan jumlah penduduk miskin tertinggi di Kalimantan
Selatan. Titik balik ini tentunya harus terus dijaga dan dipantau, sehingga terus mengalami penurunan dari tahun ke tahun. Salah satu caranya dengan memfokuskan program pengentasan pada kantongkantong kemiskinan di sektor pertanian. Sektor pertanian penting untuk terus dikembangkan dalam upaya meningkatkan pembangunan perekonomian wilayah Kabupaten Hulu Sungai Utara dengan memperhatikan sumber daya alam dan sumber daya manusia (BPS HSU, 2017).

Penelitian ini bertujuan untuk mengetahui: (i) kontribusi tiap sub sektor pertanian terhadap PDRB di daerah Kabupaten Hulu Sungai Utara tahun 2013 2017, (ii) posisi tiap sub sektor pertanian dalam perekonomian Kabupaten Hulu Sungai Utara tahun 2013-2017, (iii)pertumbuhan tiap sub sektor pertanian terhadap PDRB di daerah Kabupaten Hulu Sungai Utara tahun 2013-2017, (iv) sub sektor yang menjadi sub sektor pertanian basis dan non basis dalam perekonomian wilayah Kabupaten Hulu Sungai Utara tahun 2013-2017.

\section{METODE PENELITIAN}

\section{Lokasi dan Waktu Penelitian}

Penelitian ini dilaksanakan di Kabupaten Hulu Sungai Utara mulai dari bulan bulan Januari 2019 sampai April 2019.

\section{Jenis dan Sumber Data}

Jenis data yang digunakan dalam penelitian ini adalah data sekunder yang diperoleh dari Badan Pusat statistik (BPS) Kabupaten Hulu Sungai Utara, Dinas Pertanian Kabupaten Hulu Sungai Utara, serta Dinas Perikanan Kabupaten Hulu Sungai Utara.

\section{Metode/Jenis Penelitian}

Metode pengumpulan data yang digunakan adalah metode dokumentasi dari data sekunder yaitu metode yang mengumpulkan data dan hal-hal yang berupa catatan, transkrip, buku, surat 
kabar, majalah, notulen, raport, agenda dan sebagainya (Arikunto, 2006).

\section{Analisis Data}

Terdapat empat metode analisis data yang digunakan untuk menjawab 4 (empat) masalah dari penelitian ini. Metode analisis yang digunakan yaitu, analisis kontribusi, Tipologi Klassen, Shift Share, LQ (Location Quotient).

Menjawab tujuan pertama digunakan analisis kontribusi.

Rumusan kontribusi yang digunakan yaitu:

Kontribusi $=\frac{x}{y} \times 100 \%$ atau

Kontribusi $=\frac{\text { Sektor Pertanian }}{P D R B} \times 100 \%$
Keterangan:

$\mathrm{X}=$ Sektor Pertanian

$\mathrm{Y}=$ Produk Domestik Regional Bruto

Menjawab tujuan kedua digunakan analisis Tipologi Klassen. Tipologi Klassen adalah salah satu alat analisis ekonomi regional yang dapat digunakan untuk mengetahui klasifikasi sub sektor pertanian perkonomian wilayah Kabupaten Hulu Sungai Utara. Analisis tipologi klassen digunakan dengan tujuan mengidentifikasi posisi sub sektor pertanian perekonomian di Kabupaten Hulu Sungai Utara dengan memperhatikan sub sektor pertanian perekonomian Provinsi Kalimantan Selatan sebagai daerah referensi(Sjafrizal, 2008).

\begin{tabular}{|c|c|}
\hline $\begin{array}{c}\text { Kuadran I } \\
\text { Sektor maju dan tumbuh dengan pesat } \\
\text { si }>\text { s dan ski>sk }\end{array}$ & $\begin{array}{c}\text { Kuadran II } \\
\text { Kektor maju tapi tertekan } \\
\text { si<s dan ski }>\text { sk }\end{array}$ \\
\hline $\begin{array}{c}\text { Kuadran III } \\
\text { Sektor potensial atau masih dapat berkembang } \\
\text { si>s dan ski<sk }\end{array}$ & $\begin{array}{c}\text { Kuadran IV } \\
\text { Sektor relatif tertinggal } \\
\text { si<s dan ski<sk }\end{array}$ \\
\hline
\end{tabular}

Gambar 1. Matriks Tipologi Klassen

Menjawab tujuan ketiga menggunakan analisis Shift Share. Analisis shift share adalah suatu teknik membagi atau menguraikan pertumbuhan ekonomi suatu daerah sebagai perubahan atau peningkatan nilai suatu variabel/indikator pertumbuhan perekonomian suatu wilayah dalam kurun waktu tertentu.Metode yang digunakan dalam penelitian ini adalah analisis shift share Esteban Marquilas. Analisis shift share Esteban Marquilas merupakan modifikasi dari analisis shift share klasik. Modifikasi tersebut meliputi pendefinisian kembali kedudukan atau keunggulan kompetitif sebagai komponen ketiga dari teknik shift share dan menciptakan komponen shift share yang keempat yaitu pengaruh alokasi (Aij).

a. Komponen Pertumbuhan Regional (PR)

Keterangan:

$$
\mathrm{PRij}=(\mathrm{Ra}) / \mathrm{Yij}
$$

PRij=Komponen pertumbuhan regional sektor pertanian untuk wilayah Kabupaten Hulu Sungai Utara

Yij =Pendapatan dari sektor pertanian pada wilayah Kabupaten Hulu Sungai Utara

b. Komponen Pertumbuhan Proporsional (PP)

$P P i j=(R i-R a) Y i j$; dimana PPij adalah komponen pertumbuhan proporsional sektor pertanian untuk wilayah Kabupaten Hulu Sungai Utara. Dengan indikator sebagai berikut:

- PPij <0, menunjukkan bahwa sektor pertanian pada wilayah Kabupaten Hulu Sungai Utara pertumbuhannya lambat.

- PPij >0, menunjukkan bahwa sektor pertanian pada wilayah Kabupaten Hulu Sungai Utara pertumbuhannya cepat.

c. Komponen Pertumbuhan Pangsa Wilayah (PPW)

PPWij=(ri-Ri)Yij ;dimana PPWij adalah komponen pertumbuhan pangsa 
wilayah sektor pertanian untuk wilayah Kabupaten Hulu Sungai Utara, dengan indikator sebagai berikut:

- PPWij > 0, berarti sektor pertanian pada wilayah Kabupaten Hulu Sungai Utara mempunyai daya saing yang baik dibandingkan dengan wilayah lainnya.

- PPWij < 0, berarti sektor pertanian pada wilayah Kabupaten Hulu Sungai Utara mempunyai daya saing yang kurang baik dibandingkan dengan wilayah lainnya.

d. Persentase ketiga pertumbuhan wilayah dapat dirumuskan:

$$
\begin{aligned}
& \% \text { PRij=(PRij)/Yij*100\% } \\
& \% \text { PPij=(PPij)/Yij*100\% } \\
& \% \text { PPWij=(PPWij)/Yij*100\% }
\end{aligned}
$$

Menjawab tujuan keempat menggunakan analisis LQ (Location Quotient). Location Quotient adalah suatu metode untuk menghitung perbandingan relatif sumbangan nilai sebuah sektor di suatu daerah (dalam penelitian ini adalah Kabupaten Hulu Sungai Utara) terhadap sumbangan nilai tambah sektor yang bersangkutan dalam skala provinsi.
Rumus LQ dapat dituliskan:

$$
L Q=\frac{v i(s) / v(s)}{V i r / V r}
$$

Keterangan:

LQ : Indeks Location Quotient

vi (s) : Pendapatan subsektor pertanian pada daerah Kabupaten Hulu Sungai Utara $\mathrm{v}(\mathrm{s})$ : Pendapatan total sektor pertanian daerah Kabupaten Hulu Sungai Utara Vi r : Pendapatan subsektor pertanian pada daerah Provinsi Kalimantan Selatan V r: Pendapatan total sektor pertanian daerah Provinsi Kalimantan Selatan Kriteria nilai LQ yakni:

LQ>1 : Sektor basis

$\mathrm{LQ}=1:$ Sektor tertutup

LQ $<1$ : Sektor non basis

\section{HASIL DAN PEMBAHASAN}

\begin{abstract}
Analisis Kontribusi
Analisis kontribusi yaitu suatu analisis yang digunakan untuk mengetahui seberapa besar kontribusi dapat disumbangkan dan output setiap subsektor pertanian di Kabupaten Hulu Sungai Utara.
\end{abstract}

Tabel 1. Kontribusi sub sektor pertanian di Kabupaten Hulu Sungai Utara Tahun 2013-2017

\begin{tabular}{lccccc}
\hline Tabsektor & $2013(\%)$ & $2014(\%)$ & $2015(\%)$ & $2016(\%)$ & $2017(\%)$ \\
\hline Tanaman Pangan & 61,01 & 62,34 & 63,66 & 52,29 & 61,07 \\
Hortikultura & 1,40 & 1,33 & 1,26 & 1,22 & 1,24 \\
Perkebunan & 11,52 & 10,59 & 9,75 & 11,04 & 10,54 \\
Peternakan & 21,31 & 20,76 & 20,52 & 23,63 & 22,26 \\
Perikanan & 48,86 & 48,09 & 48,86 & 51,47 & 52,90 \\
\hline
\end{tabular}

Berdasarkan tabel diatas dari tahun 2013-2017 kontribusi dari setiap sub sektor mengalami nilai yang fluktuatif atau turun naik. Subsektor tanaman pangan dalam lima tahun terakhir mengalami kenaikan sebanyak $1,01 \%$, subsektor hortikultura dalam lima tahun terakhir mengalami penurunan $0,88 \%$, subsektor perkebunan dalam lima tahun terakhir juga mengalami penurunan sebanyak $0,91 \%$ subsektor peternakan dalam lima tahun terakhir mengalami kenaikan sebanyak $1,04 \%$ dan subsektor perikanan dalam lima tahun terakhir juga mengalami kenaikan sebanyak $1,08 \%$. Nilai kontribusi terbesar ada pada subsektor tanaman pangan, karena subsektor inilah yang paling banyak di kerjakan oleh masyarakat di Kabupaten Hulu Sungai Utara dan sektor ini yang paling banyak menyerap tenaga kerja walaupun kenaikan persentasinya hanya $1,01 \%$ tapi itu cukup menaikkan nilai kontribusi pada tahun terakhir yaitu tahun 2017. Sedangkan subsektor hortikultura 
adalah subsektor yang memiliki nilai kontribusi terkecil.

Ini pun selaras dengan hasil penelitian Risnawati (2016) di Kabupaten Jeneponto menunjukkan bahwa sub sektor tanaman pangan juga merupakan subsektor yang memiliki kontribusi tertinggi yaitu sebesar 78,62 persen dan subsektor kehutanan adalah subsektor yang memilki kontribusi terendah sebesar 0,05 persen. Sejalan dengan pendapat Sedana, dkk (2013) dalam menentukan besarnya kontribusi PDRB subsektor pertanian terhadap total PDRB sektor pertanian digunakan klasifikasi kriteria kontribusi dimana apabila persentase yang dicapai diatas 50 persen berarti sangat baik dan persentase yang dicapai kurang dari 10 persen berarti kurang baik.

Ini pun berhubungan dan sesuai dengan pendapat Halim (2010) bahwa besar kecilnya kontribusi yang dapat disumbangkan dan outputnya setiap subsektor pertanian sangat mempengaruhi peranan dalam perekonomian di tiap kabupaten dan mampu meningkatkan kesejahteraan masyarakat terutama masyarakat yang dominannya bekerja sebagai petani.

\section{Analisis Tipologi Klassen}

Dengan menggunakan matriks tipologi klassen setiap sub sektor pertanian dapat dikelompokkan ke dalam empat klasifikasi dengan membandingkan ratarata laju pertumbuhan sub sektor tingkat Kabupaten Hulu Sungai Utara dengan Provinsi Kalimantan Selatan dan nilai dan kontribusi masing-masing.

\begin{tabular}{|c|c|}
\hline Kuadran I & Kuadran II \\
Subsektor maju dan tumbuh dengan pesat & \\
$\mathrm{Si}>\mathrm{S}$ dan Ski $>\mathrm{Sk}$ & Subsektor maju tapi tertekan \\
Kuadran III & $\mathrm{Si}<\mathrm{S}$ dan $\mathrm{Ski}>\mathrm{Sk}$ \\
\hline Subsektor potensial atau masih dapat berkembang & Kuadran IV \\
$\mathrm{Si}>\mathrm{S}$ dan Ski<Sk & Subsektor relatif tertinggal \\
TanamanPangan & $\mathrm{Si}<\mathrm{S}$ dan Ski<Sk \\
Holtikultura & \\
Perkebunan & \\
Peternakan & \\
Perikanan & \\
\hline
\end{tabular}

Gambar 2. Matriks Tipologi Klassen

Berdasarkan hasil analisis tipologi klassen tidak terdapat subsektor pertanian dalam PDRB Kabupaten Hulu Sungai Utara tahun 2013-2017 yang termasuk dalam klasifikasi subsektor maju dan pesat dan klasifikasi subsektor maju tapi tertekan atau laju pertumbuhan sektor tertentu dalam PDRB kabupaten (si) lebih kecil dibandingkan laju pertumbuhan sektor tersebut dala PDRB daerah yang menjadi referensi atau provinsi (s) dan memiliki nilai kontribusi sektor terhadap PDRB kabupaten (ski) lebih besar dibandingkan kontribusi sektor tersebut PDRB daerah yang menjadi referensi atau provinsi (sk) serta subsektor relatif tertinggal atau laju pertumbuhan sektor tertentu dala PDRB kabupaten lebih kecil dibandingkan laju peretumbuhan sektor tersebut dala PDRB provinsi dan sekaligus memiliki nilai kontribusi sektor terhadap PDRB kabupaten yang lebih kecil dibandingkan kontribusi sektor tersebut terhadap PDRB provinsi. Kelima subsektor pertanian berada dalam klasifikasi subsektor potensial atau masih dapat berkembang yaitu subsektor tanaman pangan, subsektor hortikultura, subsektor perkebunan, subsektor peternakan dan subsektor perikanan. Hal tersebut berarti kelima subsektor memiliki nilai pertumbuhan PDRB kabupaten yang lebih besar dibandingkan nilai pertumbuhan PDRB Kalimantan Selatan serta sekaligus 
memiliki kontribusi yang lebih kecil dibandingkan dengan nilai kontribusi subsektor tersebut terhadap PDRB daerah lain yang ada di Kalimantan Selatan. Pengelompokkan kelima sub sektor di kuadran III (tiga) tersebut menunjukkan bahwa kelima sub sektor tersebut masih bisa berkembang di masa yang akan datang. Sjafrizal (2008) mengemukakan bahwa pengelompokkan sub sektor tersebut dapat berubah sesuai dengan berkembangnya laju pertumbuhan dan tingkat pendapatan per kapita daerah Kabupaten Hulu Sungai Utara.

\section{Analisis Shift Share}

Tabel 2. Analisis shift share menurut lapangan usaha di Kabupaten Hulu Sungai Utara berdasarakan komponen pertumbuhan wilayah tahun 2013-2017

\begin{tabular}{lcccccc}
\hline \multicolumn{1}{c}{ Lapangan Usaha } & Prij & PRij $(\%)$ & PPij(\%) & Ket. & PPWij(\%) & Ket. \\
\hline Tanaman Pangan & $44.777,74$ & 16,42 & 1,83 & Cepat & $-5,53$ & Tidak Kompetitif \\
Hortikultura & $1.027,52$ & 16,42 & $-1,94$ & Lambat & $-13,95$ & Tidak Kompetitif \\
Perkebunan & $8.454,99$ & 16,42 & $-7,14$ & Lambat & $-6,25$ & Tidak Kompetitif \\
Perikanan & $15.640,28$ & 16,42 & 4,19 & Cepat & $-3,00$ & Tidak Kompetitif \\
Peternakan & $35.860,35$ & 16,42 & 6,42 & Cepat & $-0,93$ & Tidak Kompetitif \\
\hline
\end{tabular}

Berdasarkan tabel diatas dapat dilihat bahwa pertumbuhan subsektor pertanian di Kabupaten Hulu Sungai Utara dipengaruhi secara positif yaitu senilai $16,42 \%$ oleh pertumbuhan perekonomian Provinsi Kalimantan Selatan. Subsektor pertanian Kabupaten Hulu Sungai Utara yang mendapat pengaruh paling besar dari pertumbuhan perekonomian Provinsi Kalimantan Selatan adalah subsektor tanaman pangan diikuti subsektor perikanan, sub sektor peternakan, subsektor perkebunan dan yan terkecil mendapat pengaruh dari pertumbuhan perekonomian Provinsi Kalimantan Selatan adalah subsektor hortikultura.

Berdasarkan tabel diatas dapat dilihat bahwa ada tiga subsektor dalam sektor pertanian di Kabupaten Hulu Sungai Utara yang memiliki nilai pertumbuhan proporsional positif. Dimulai dari yang memiliki nilai (PP) terbesar yaitu subsektor perikanan, kemudian sub sektor
Analisis Shift Share adalah analisis untuk mengetahui Pertumbuhan sub sektor pertanian wilayah Kabupaten Hulu Sungai Utara yang dipengaruhi oleh beberapa komponen pertumbuhan wilayah, yaitu pertumbuhan regional (PR), pertumbuhan proporsional (PP) dan pertumbuhan pangsa wilayah (PPW).Jika ketiga komponen tersebut memiliki nilai positif, maka laju pertumbuhan sub sektor dalam sektor pertanian di Kabupaten Hulu Sungai Utara mengalami peningkatan. Tetapi jika ketiga komponen tersebut memiliki nilai negatif, maka laju pertumbuhan sub sektor dalam sektor pertanian di Kabupaten Hulu Sungai Utara penurunan. Hal tersebut dapat dilihat pada tabel berikut.

peternakan dan subsektor tanaman pangan.Ketiga subsektor ini memiliki nilai pertumbuhan proporsional subsektor positif (PPij>0) yang artinya ketiga subsektor ini memiliki tingkat pertumbuhan yang cepat. Kemudian dua subsektor pertanian yang tersisa mendapat nilai pertumbuhan proporsional negatif, yaitu subsektor perkebunan dan subsektor hortikultura. Kedua subsektor pertanian ini mendapatkan nilai pertumbuhan proporsional subsektor pertanian negatif $(\mathrm{PPij}<0)$ yang berarti tingkat pertumbuhan kedua subsektor ini lambat.

Berdasarkan hasil perhitungan PPWij dapat dilihat bahwa subsektor dalam sektor pertanian Kabupaten Hulu Sungai Utara memiliki nilai negatif dan tidak ada yang memiliki nilai positif. Nilai pertumbuhan pangsa wilayah negatif artinya sub sektor tersebut memiliki daya saing yang kurang baik terhadap subsektor dalam sektor pertanian di wilayah lain 
(kabupaten/kota) di Provinsi Kalimantan Selatan (tidak Kompetitif), sedangkan nilai positif artinya subsektor tersebut memiliki daya saing yang baik terhadap subsektor di wilayah (kabupaten/kota) lain di Provinsi Kalimantan Selatan. Subsektor yang memiliki pertumbuhan wilayah yang tidak kompetitif adalah sub sektor tanaman pangan, hortikultura, perkebunan, peternakan dan perikanan

\section{Analisis LQ}

Tabel 3. Nilai LQ berdasarkan PDRB atas dasar harga konstan 2000 Kabupaten Hulu Sungai Utara dan Provinsi Kalimantan Selatan tahun 2013-2017

\begin{tabular}{cccccc}
\hline \multirow{2}{*}{ Tahun } & \multicolumn{5}{c}{ Lapangan Usaha } \\
\cline { 2 - 6 } & Tanaman Pangan & Hortikultura & Perkebunan & Peternakan & Perikanan \\
\hline 2013 & 1,32 & 0,90 & 0,23 & 1,61 & 1,44 \\
2014 & 1,37 & 0,88 & 0,21 & 1,62 & 1,44 \\
2015 & 1,38 & 0,84 & 0,20 & 1,58 & 1,39 \\
2016 & 1,13 & 0,82 & 0,24 & 1,81 & 1,54 \\
2017 & 1,27 & 0,79 & 0,22 & 1,58 & 1,44 \\
Rata-rata & 1,29 & 0,85 & 0,22 & 1,64 & 1,45 \\
\hline
\end{tabular}

Berdasarkan perhitungan Location Quotient (LQ), subsektor dalam sektor pertanian yang termasuk subsektor basis dalam perekonomian Kabupaten Hulu Sungai Utara adalah subsektor peternakan, sub sektor perikanan dan subsektor tanaman pangan. Subsektor dalam sektor pertanian yang termasuk subsektor non basis dalam perekonomian Kabupaten Hulu Sungai Utara adalah subsektor holtikultura dan subsektor perkebunan. Sesuai dengan pendapat Tarigan (2008) analisis LQ pada subsektor pertanian di Kabupaten Hulu Sungai Utara tiga subsektor yang basis karena adanya kebijakan pemerintah daerahyaitu pembangunan ekonomi kerakyatan dengan meningkatkan program-program prorakyat terutama yang berbasis pertanian. Walaupun ada dua subsektor yang tidak basis, tetapi pada dasarnya sub sektor pertanian merupakan penunjang dari keberadaan subsektor basis lainnya serta jika sektor/sub sektor tersebut berada pada posisi basis pada suatu daerah,berarti peran sektor atau subsektor tersebut lebih menonjol atau sama menonjolnya dengan peran sektor atau subsektor yang sama secara provinsi.

Arsyad (1999), menyatakan bahwa faktor penentu utama pertumbuhan ekonomi suatu daerah adalah berhubungan langsung dengan permintaan akan barang dan jasa dari luar daerah. Kegiatan basis memiliki peran yang sangat penting sebagai penggerak pertama yang akan berdampak pada setiap perubahan pendapatan sektor tersebut serta memberikan efek pengganda terhadap perekonomian agregat daerah.

\section{KESIMPULAN}

Semua subsektor pertanian dalam lima tahun terakhir mengalami nilai kontribusi yang turun naik atau tidak stabil, berada pada kuadran III yaitu sektor potensial atau masih bisa dikembangkan, subsektor perikanan, subsektor peternakan dan subsektor tanaman pangan mengalami pertumbuhan yang cepat atau mendapat nilai positif dalam pertumbuhan proposionalnya (Pp), mengalami pertumbuhan wilayah $(\mathrm{Pw})$ yang kurang baik atau tidak kompetitif jika dibandingkan dengan wilayah-wilayah lain di Provinsi Kalimantan Selatan. Subsektor tanaman pangan, peternakan dan perikanan merupakan subsektor basis sedangkan subsektor hortikultura dan subsektor perkebunan adalah sub sektor non basis dalam perekonomian Kabupaten Hulu Sungai Utara. Subsektor tanaman pangan 
yang paling tinggi kontribusinya terhadap sektor pertanian di Kabupaten Hulu Sungai Utara.

\section{DAFTAR PUSTAKA}

Arikunto, S. (2006). Prosedur Penelitian Suatu Pendekatan Praktik. Jakarta: Rineka Cipta.

Arsyad, L. (1999). Pengantar Perencanaan dan Pembangunan Ekonom I Daerah. Yogyakarta : BPFE.

BPS HSU. (2017). Statistik Daerah Kabupaten Hulu Sungai Utara Tahun 2017. Amuntai: BPS Kabupaten Hulu Sungai Utara.

Halim, H. (2010). Akuntansi Daerah Sektor Publik. Jakarta: Salemba.

Sedana, I. K. A., Artana, M. dan Suwena, K. R. (2013). Efektivitas dan kontribusi pajak hotel dan pajakrestoran terhadap Pendapatan Asli Daerah (PAD) di Kabupaten Gianyar Tahun 2008-2012. Jurnal Pendidikan Undiksha, 3(1), DOI: http://dx.doi. org/10.23887/jjpe.v3i1.1285.

Kuncoro, M. (2001). Metode Kuantitatif: Teori dan Aplikasi Untuk Bisnis dan Ekonomi. Yogyakarta: UPP AMP YKPN

Risnawati. (2016). Kontribusi Sektor Pertanian Terhadap Produk Domestik Regional Bruto (PDRB) di Kabupaten Jeneponto. Makassar: Universitas Islam Negeri Alauddin.

Tarigan, Robinson. (2008). Ekonomi Regional Teori dan Aplikasi Edisi IV. Jakarta: PT Bumi Aksara.

Sjafrizal. (2008). Ekonomi Regional. Padang: Baduose Media. 